\title{
Poluição hídrica: aspectos fundamentais da tutela jurídico-penal no Brasil $^{1}$
}

Bruna Azevedo de Castro

\section{Resumo}

Há tempos o meio ambiente vem sido visto de forma mais cautelosa por certos países, tendo constituído tópico de discussão em vários desses. Todavia, foi com os desastres naturais ocorridos que o assunto meio ambiente passou a ser pauta de discussão em todo o mundo, globalizando assim a questão, vez que todo o mundo se abala com os transtornos ambientais. Diante dessa perspectiva, o presente trabalho tem por escopo enfocar a questão da poluição hídrica e seu tratamento no ordenamento jurídico-penal brasileiro, promovendo, antes, a pontuação de conceitos extrajurídicos essenciais ao esclarecimento do tema, um breve apontamento histórico de sua tutela jurídica e, por fim, ponderar, criticamente, aspectos fundamentais do tratamento jurídico-penal contemporâneo.

Palavras-Chave: Direito Penal; Ambiente; Poluição hídrica.

\section{Introdução}

A degradação ambiental proveniente do desenvolvimento tecnológico e industrial é um fenômeno mundial, impossível de ser ignorado, alvo de constante e crescente preocupação desde as últimas décadas do século passado e início do presente decênio.

O progresso econômico, tecnológico, industrial, exige um preço a ser pago pelo próprio homem. De fato, "as sociedades industriais são vítimas de suas próprias obras, que atingem não apenas seu meio ambiente, mas, também, todo o conjunto de seu espaço vital, para atingir também todo o Planeta, na medida em que esse espaço vital assume dimensões planetárias" (PIRANGELLI, 1989, p. 378).

A preservação ambiental, neste sentido, revela-se um dos mais palpitantes temas de preocupação e discussão dos organismos internacionais, sobretudo a partir da Conferência de Estocolmo, em 1972 (PRADO, 2005, p. 64), conduzindo a uma verdadeira

\footnotetext{
1 Artigo apresentado ao Curso de Especialização em Direito e Processo Penal da Universidade Estadual de Londrina (2006), como requisito parcial à obtenção do título de Especialista, elaborado sob orientação do prof. Dr. Luiz Regis Prado.

2 Estudante de Direito da Universidade Estadual de Londrina.
} 
globalização desta questão, antes restrita a "determinados segmentos sociais", restando hoje evidente que, "de uma forma ou de outra, a todos atinge" (CARVALHO, 1997, p. 53-69).

A necessidade de se utilizar o ambiente aumenta da proporção do incremento das necessidades básicas do homem, conduzido, justamente, pelo progresso econômico.

Não seria razoável postular a paralisação do desenvolvimento econômico em nome da preservação ambiental; em verdade, qualquer proposta neste sentido seria extremamente ilusória.

A melhor proposta, indubitavelmente, propugna pelo justo equilíbrio entre desenvolvimento econômico, proteção e restauração do ambiente, como a única forma apta a garantir a sadia qualidade de vida das presentes e futuras gerações (PRADO, 2005, p. 81).

"Novos" interesses emergem da dinâmica social; com eles, sua urgente necessidade de proteção. Os bens ou interesses supra-individuais representam o abandono do individualismo, a concepção de Estado de Direito democrático, voltado ao bem-estar social, o espírito de coletividade que, frise-se, jamais poderá deixar de ter o homem - considerado como pessoa - no centro de todo o sistema.

O ambiente, antes de ser reconhecido como bem indispensável à sobrevivência humana, fora objeto de uma tutela insuficiente e notadamente individualista, de modo que os poucos dispositivos - inclusive penais - dirigidos à proteção de elementos naturais, tinham caráter predominantemente patrimonial.

A Constituição Federal de 1988 rechaça a postura individualista do Estado e conclama o Estado Social e Democrático de Direito, desde já no preâmbulo do texto constitucional, a cumprir a inarredável função de "assegurar o exercício dos direitos sociais e individuais, a liberdade, a segurança, o bem-estar [...]", e, logo adiante, no bojo dos fundamentos da República Federativa - Art. 3․

A tutela jurídica do ambiente, como não poderia deixar de ser, é reconhecida pelo Texto de 88, Art. 225, como indispensável à sadia qualidade de vida humana, apontando, inclusive, a necessidade de criminalizar condutas a ele atentatórias no §3ำ do referido artigo.

Faz-se imperioso notar a maior racionalidade da concepção antropo-ecocêntrica de ambiente, considerando-o não como "um dado absoluto, mas sim referido, afeto ao homem, como seu espaço vital de realização individual e coletiva" (PRADO, 2005, p. 81). 
O ambiente, objeto de estudo da Ecologia (DOTTI, 1990, p. 245-257), constitui um bem jurídico supra-individual, de cunho difuso, dos mais complexos da pós-modernidade. Um dos fatores desta complexidade é o alto grau de interação entre seus componentes, os elementos naturais e, sobretudo, a interação destes com o ser humano, sua interferência direta ou indireta na qualidade de vida.

Diante das variadas significações que a palavra "ambiente" pode alcançar, faz-se necessário delimitar seu conteúdo enquanto objeto de tutela penal. Para tanto, adota-se uma acepção ampla, porém não totalizadora ou globalista, segundo a qual ambiente abrange não só os recursos naturais existentes na biosfera, mas a relação do homem com esses elementos, em vista da preservação de sua qualidade de vida (PRADO, 2005, p. 77).

A proteção jurídico-penal das águas, neste contexto, assume relevância indiscutível, visto que trata de um recurso natural essencial à sobrevivência humana (KÖELER, 2000, p. 94), por meio da tutela jurídica de restrição da liberdade humana mais incisiva entre todas as demais.

O presente estudo intenta enfocar a questão da poluição hídrica e seu tratamento no ordenamento jurídico-penal brasileiro, promovendo, antes, a pontuação de conceitos extrajurídicos essenciais ao esclarecimento do tema, um breve apontamento histórico de sua tutela jurídica e, por fim, ponderar, criticamente, aspectos fundamentais do tratamento jurídico-penal contemporâneo.

\section{A poluição hídrica}

Faz-se mister assentar um conceito de poluição hídrica, sobretudo com vistas a circunscrever o bem jurídico tutelado (DARIVA, 2002, p. 64) pelo tipo de injusto que será objeto de reflexões posteriores.

A água é considerada o melhor solvente que se tem conhecimento, sendo nela encontradas diversas substâncias e elementos dissolvidos; daí a afirmação de que a pureza da água é hipotética, pois só pode ser obtida em laboratório, por meio de aparelhos e cuidados especiais, como seu isolamento do ar atmosférico após o processo de purificação, pois, "do contrário, ela dissolverá instantaneamente gás carbônico, oxigênio e outros gases" (KUWABARA, 1982, p. 3). 
Trata-se de um componente fundamental dos organismos vivos, correspondendo a $70 \%$ a 90\% do protoplasma dos animais (CARVALHO, 1975, p. 51). Não é apenas destinada ao consumo humano direto por ingestão, mas também para diversos usos domésticos (MILARÉ, 2004, p. 174), industriais, conservação da flora, irrigação, dessedentação de animais, piscicultura, lazer, geração de energia elétrica, dissolução de resíduos industriais, sanitários, transporte, etc (BRANCO, 1972, p. 91-92).

Assim, define-se água a forma líquida do elemento químico composto por dois átomos de hidrogênio e um de oxigênio, essencial para a sobrevivência e sadia qualidade de vida humana, que cobre quase todo o globo terrestre - hidrosfera, compreendendo oceanos, mares e águas continentais (KÖELER, 2000, p. 95).

A poluição hídrica, espécie do gênero poluição ambiental, possui conteúdo de intrincada determinação. A própria palavra "poluição" é conceituada de tantas formas diferentes, sob diversas óticas, que não é difícil notar certa fluidez em sua definição.

Poluir o ambiente significa sujar, corromper, macular, conspurcar, tornar prejudicial à saúde (FERREIRA, 2004, p. 1594), segundo a definição lingüística mais simples.

Como bem adverte Odum, a poluição "consiste numa alteração indesejável das características físicas, químicas ou biológicas do ar, do solo e da água que podem afectar, ou afectarão, prejudicialmente a vida do homem ou a de espécies desejáveis, os nossos processos industriais, condições de vida e patrimônio cultural" (ODUM, 2004, p. 475).

Adstrito a uma concepção mais restrita, Fellenberg $(1980$, p. 1) considera poluição ambiental os fatores capazes de comprometer a saúde ou a sobrevivência humana, excluindo conscientemente quaisquer "aspectos puramente estéticos ou referentes à proteção da natureza e da paisagem".

Entrementes, parece mais compatível com a moderna tendência de proteção ambiental, aliada às preocupações mundiais de degradação dos recursos hídricos, uma aproximação conceitual de poluição hídrica apontada pelo primeiro autor, considerando-a como a alteração, provocada pelo homem, das propriedades físicas, químicas ou biológicas da água, capaz não só de afetar direta ou indiretamente a vida humana, mas também as formas de vida aquáticas desejáveis.

A poluição hídrica na atualidade possui causas evidentes, que pertencem a duas ordens de fato distintas: o crescimento da população humana e incremento da urbanização; 
e o desenvolvimento industrial, que demanda quantidades cada vez maiores de água, despejando nos cursos d'água mais resíduos provenientes destas atividades (DORST, 1973, p. 234).

Neste diapasão, cumpre salientar que há uma estreita ligação entre os aspectos quantitativos e qualitativos dos recursos hídricos; assim, verifica-se que "o aumento do consumo das águas, diminui a capacidade do corpo receptor, fazendo-o mais vulnerável à degradação qualitativa" (RUFINO, 1990, p. 242).

A forma mais comum de poluição hídrica é a proveniente de substâncias orgânicas, acarretada pelo lançamento de esgotos domésticos nos cursos d'água. "O esgoto pode estimular o crescimento e a multiplicação de bactérias e fungos" (MELLANBY, 1982, p. 32), agentes das denominadas "doenças hídricas" (CARVALHO, 1997, p. 118).

Os detritos industriais também constituem importantíssimo fator poluente dos recursos hídricos (PIRANGELLI, p. 379), em função de sua natureza, em geral, química, por exemplo, os hidrocarbonetos e os detergentes sintéticos (DORST, p. 236).

Menos freqüente, mas não menos danosa, é a poluição agro-pastoril, decorrente de "atividades ligadas à agricultura e a pecuária através de defensivos agrícolas; de fertilizantes; de excrementos de animais e de erosão"(DERISIO, 2000, p. 20) ${ }^{3}$. Neste particular, destaca-se o alto risco de contaminação de águas subterrâneas, "por força da participação de poluentes, como nitratos e agrotóxicos" (MILARÉ, p. 177).

Justamente em razão da ampla acepção que pode atingir o conceito de poluição, o legislador ordinário procurou firmar, em épocas diferentes e sob prismas distintos, marcos conceituais aptos a restringir tal âmbito de compreensão e, portanto, tornar a questão menos obscura para os fins de intervenção jurídica, tarefa na qual não demonstrou lograr êxito (DARIVA, p. 64)

A poluição decorrente de excrementos de animais, por exemplo, constitui uma espécie de poluição não relevante para fins de intervenção penal, qual seja a chamada "poluição natural", freqüentemente causada por "chuvas e escoamento superficial; salinização; decomposição de vegetais e animais mortos" (DERÍSIO, J. C., op. cit., p. 20), bem como por erupções vulcânicas e excrementos de animais (ART, Henry W. Dicionário de Ecologia e Ciências Ambientais. Trad. Mary Amazonas Leite de Barros. 2. ed. São Paulo: UNESP, Companhia Melhoramentos, 2001, p. 419).

4 Aponta Silvia Luiza Dariva que a primeira definição jurídica de poluição hídrica foi elaborada pelo Decreto n. 50.877/61, que dispõe sobre o lançamento de resíduos tóxicos ou oleosos, nas águas interiores e litorâneas do País, em seu Art. 3ํ, como sendo "qualquer alteração das propriedades físicas, químicas e biológicas das águas, que possa importar em prejuízo à saúde, à segurança e ao bem-estar das populações e ainda comprometer a sua utilização para fins agrícolas, industriais, comerciais, recreativos e principalmente 
A Lei n.o 6.938/81, em seu Art. 3ํ, III, apresenta um conceito genérico de poluição, como a "degradação da qualidade ambiental resultante de atividades que direta ou indiretamente: a) prejudiquem a saúde, a segurança e o bem-estar da população; criem condições adversas às atividades sociais e econômicas; c) afetem desfavoravelmente a biota; d) afetem as condições estéticas ou sanitárias do meio ambiente; e) lancem matérias ou energia em desacordo com os padrões ambientais estabelecidos" (CARVALHO, p. 59).

A vigente Lei dos Crimes Ambientais - Lei n. 9.605/98 -, como há de se observar mais detalhadamente adiante, não encerra as controvérsias provenientes do tratamento penal anterior, no que diz respeito à sua excessiva imprecisão e, por isso, de sofrível aplicabilidade ${ }^{5}$.

Do Art. $54^{6}$ da referida lei, extrai-se que o conceito jurídico-penal de poluição, genericamente construído, como já salientado, vincula-se, ao menos, à ocorrência de perigo ${ }^{7}$ de "danos à saúde humana" ou à concreta constatação de "mortandade de animais ou destruição significativa da flora".

Assim, como o legislador de 1998 conteve-se no sentido de formular um conceito específico de poluição hídrica e, quiçá, prover-lhe um tratamento mais adequado, é possível concluir que esta consiste na alteração, provocada pelo homem, das propriedades físicas, químicas ou biológicas da água, que lese ou exponha a perigo a vida humana ou, ainda provoque danos concretos e relevantes às desejáveis formas de vida aquáticas - fauna e flora.

É pertinente frisar, desde já, a insegurança e imprecisão conceitual proveniente deste tipo penal, dentre outras incongruências a serem aventadas ulteriormente, que

a existência normal da fauna aquática". Posteriormente, firmaram o conceito jurídico de poluição das águas o Decreto-lei n.ㅇ 221/67, no Art. 37 §1ㅇe e o Decreto n.ㅇ 73.030/73, sendo que este assentou conceito mais amplo que aquele (DARIVA, S. L., op. cit., p. 64).

5 A precedente proteção jurídico-penal do ambiente hídrico-atmosférico no Brasil, como bem observa Érika Mendes de Carvalho, em artigo publicado antes do advento da Lei 9.605/98, era composta "basicamente por leis esparsas, excessivamente prolixas e casuísticas, bem como por dispositivos do vetusto Código Penal Brasileiro", o que a caracterizava como extremamente lacunosa, incompatível com a nova ordem constitucional, que certamente demandava uma tutela ambiental mais eficaz (CARVALHO, É. M. de, op. cit., p. 57).

6 “Art. 54. Causar poluição de qualquer natureza em níveis tais que resultem ou possam resultar em danos à saúde humana, ou que provoquem a mortandade de animais ou a destruição significativa da flora. Pena reclusão, de 1 (um) a 4 (quatro) anos, e multa".

7 Trata-se de um delito de perigo concreto no que se refere à saúde humana, em que pese haver alguma discordância na doutrina pátria, consoante será exposto posteriormente. 
figuram um quadro de equívocos legislativos inadmissíveis ao Direito Penal de um Estado Democrático de Direito.

\section{Escorço histórico}

Embora acentuada a preocupação com a poluição ambiental nas últimas décadas, nas quais se tem tido maior percepção dos efeitos negativos gerados pelo desenfreado desenvolvimento das sociedades industriais, aquela constitui antiga preocupação da humanidade.

O lançamento de diversos resíduos aos rios e ao ar atmosférico, quando não tóxicos, eram no mínimo desagradáveis e, por isso, ensejaram medidas de controle por meio de decretos e normas como, por exemplo, na Grécia antiga em que os curtumes, "com seus gases de cheiro desagradável, só podiam ser construídos após autorização especial" (FELLENBERG, p. 2).

As preocupações, nesta época, eram locais e não se compreendia a dimensão da poluição ambiental ante a "capacidade de resistência da Terra" (FELLENGERG, p. 3). Em realidade, estimou-se equivocadamente o tempo que levaria a natureza para autodepurarse, sendo que tal equívoco foi percebido antes em relação aos rios e lagos.

No tocante à poluição hídrica, cumpre conceder especial destaque histórico à proteção das águas doces, sobre a qual se encontram preceitos relativos a detritos e forma de distribuição no Zend Ayesta e Escrituras (DORST, p. 234).

Na história do Direito brasileiro, a primeira previsão punitiva à poluição hídrica constou das Ordenações Filipinas, ratificadas por D. Pedro I, em 1823, em que foi explicitamente proibido "o lançamento de qualquer material que pudesse matar os peixes e sua criação ou sujar as águas dos rios e das lagoas" (DARIVA, p. 57).

Após a declaração de independência do Brasil, foi o Código Penal de 1890 em que se tipifica primeiramente o envenenamento de águas, no Art. 161, e poluição de água potável - Art. 162 (DARIVA, p. 58-59), diretiva seguida pelo Código Penal de 1940, que também previu duas modalidades delitivas, concernentes à tutela da saúde pública ${ }^{8}$.

O Código Penal de 1940 tipifica no Art. 270 o "envenenamento de água potável ou de substância alimentícia ou medicinal" e, no Art. 271 a "corrupção ou poluição de água potável". Atualmente, encontrase a primeira parte do Art. 270 e o Art. 271 tacitamente revogados pelo Art. 54 da Lei n.o9.605/98, o que é praticamente pacífico da doutrina, como se verá com mais detalhes em momento ulterior. 
Alinhando-se com as tendências internacionais de reestruturação da ordem jurídica para uma utilização racional dos recursos naturais, ocorre, no Brasil, a "constitucionalização" (PRADO, p. 63) do ambiente, com o advento da Carta de 1988.

A tutela do ambiente anterior à Lei Fundamental de 88, embora já represente uma preocupação legislativa com a degradação ambiental, como afirma Érika Mendes de Carvalho, revela-se notadamente circunstancial, "desprovida de uma visão global acerca deste bem jurídico", por meio da ponderação de "aspectos isolados relativos ao ambiente, sem, entretanto, examinar o contexto em que os problemas estavam inseridos" (CARVALHO, p. 55).

Na década de 30, diante da obsoleta proteção jurídica das águas presente no País, o Governo Provisório decretou o Código de Águas, Decreto n.o 24.643, em 10.07.1934, publicado no dia 20 e retificado no dia 27 do mesmo mês, buscando instituir medidas de utilização racional dos recursos hídricos (POMPEU, 2006, p. 151).

Entretanto, como bem se observa, o Código de Águas voltou-se não tanto à proteção dos recursos hídricos, mas ao melhor aproveitamento de sua utilização, tanto que não prevê qualquer sanção de natureza penal, e o único dispositivo que faz menção a sanções aplicáveis ao sujeito que polui ou contamina águas, o faz de forma genérica e imprecisa (DARIVA, p. 59) ${ }^{9}$.

Merece destaque, ainda, o que dispôs o Código de Pesca ${ }^{10}$ a este respeito, em seu Art. 37, determinando que "os efluentes das redes de esgotos e os resíduos líquidos ou sólidos das indústrias somente poderão ser lançados às águas quando não as tornarem poluídas" (MILARÉ, p. 178).

A partir da década de 70, outros diplomas legais aparecem regulamentando a interdição do lançamento de efluentes nos corpos d'água, dentre os quais se destacam (RUFINO, p. 244): Portaria n. 170, do MA, de 20.04.72, vedando o lançamento de detritos poluidores nas lagoas litorâneas; Decreto n. 94 de 77, proibindo a fabricação de saneantes não biodegradáveis; Resolução n. 20/86 do CONAMA, em que sobressai a previsão de medidas preventivas concernentes a águas destinadas ao abastecimento e à preservação

9 Insta reconhecer, ainda, durante décadas, e até mesmo durante a vigência do Código de Águas, a questão hídrica era tratada sob maior enfoque do Direito Privado que do Direito Público (FREITAS, Vladimir Passos de. Águas - considerações gerais. In: FREITAS, Vladimir Passos de - org. Águas. Aspectos jurídicos e ambientais. 2 ed. p. 17-28.Curitiba, Juruá, 2006, p. 19).

10 Decreto-lei n. 221, de 28.02.1967. 
ecológica, além da classificação das águas como doces, salobras e salinas e "estabelece os níveis suportáveis de presença de elementos potencialmente prejudiciais nas águas" (MILARÉ, p. 179); entre outros.

Ainda no panorama legislativo precedente à nova ordem constitucional, coube à Lei n.o 6.938/81 instituir a "Política Nacional do Meio Ambiente" e, em seu Art 15, cuja redação foi dada pela posterior Lei $n .97 .804 / 89$, prevendo um tipo penal de poluição genérica que, de seu turno, vem conceituada pelo Art. 3으, III do referido diploma legal, conforme já se observou anteriormente.

Já sob a égide da Carta de 88, foi publicada a Lei n.o 9.433/97 com vistas a regulamentar o Art. 21, XIX da Lei Maior, instituindo, pois, a Política Nacional de Recursos Hídricos e criando o Sistema Nacional de Gerenciamento de Recursos Hídricos. Esta lei ratifica o entendimento de que a água é um recurso natural limitado, razão pela qual expressamente reconhece sua qualidade de "bem de domínio público" e de valor econômico (LEME MACHADO, 2001, p. 419).

Atualmente, em sede criminal, a poluição hídrica é tratada pelo Art. 54 da Lei $\mathrm{n}$. o 9.605/98, que dispõe sobre "poluição de qualquer natureza", prevendo a modalidade culposa e omissiva, além das formas qualificadas, a qual passa-se a analisar mais criticamente nas linhas que seguem.

\section{0 atual tratamento jurídico-penal da poluição hídrica}

Quando se trata da tutela jurídico-penal do ambiente no Brasil, uma das tormentosas questões aventadas, aliada ao problema maior de sua construção adequada, concerne à "colocação topográfica das normas incriminadoras" (DOTTI, p. 254), ou melhor, “o problema técnico de sua localização sistemática" (PRADO, p. 85).

Como não figura o escopo do presente trabalho aprofundar tão intrincada questão, é suficiente asseverar que a opção feita pelo legislador brasileiro - tipificação por meio de esparsas leis setoriais (PRADO, p. 88) - não parece a mais adequada, sobretudo em razão da essencialidade do bem jurídico ambiente. Ademais, a facilidade de elaboração de projetos de leis especiais, bem como a maior simplicidade deste processo legislativo, quando em cotejo com a reforma total ou parcial do código, constitui um dos fatores explicativos do fenômeno da "hipercriminalização" (DOTTI, p. 254). 
Contrariando a tendência verificada em diversos países, o legislador brasileiro não tem se mostrado inclinado a uma "codificação" (SALES, 2004, p.134-170) de normas originalmente localizadas na legislação extravagante.

Não obstante, houve a tentativa de incorporar a matéria ambiental ao Código Penal, por meio do Anteprojeto do Código Penal - Parte Especial (PRADO, p. 88) - que, inclusive, tratava o crime de poluição de forma mais específica, reservando um tipo penal para cada espécie (poluição de águas, de estuário ou águas litorâneas, atmosférica, do solo e do subsolo).

Atualmente, o tratamento penal da poluição hídrica no Brasil esgota-se no Art. 54 da Lei n.o 9.605/98, pois, tendo este disposto amplamente sobre a poluição ambiental, revogou a primeira parte do Art. 270 e todo o Art 271 do Código Penal, bem como o Art. 15 da Lei n.․ 6.938/81 (PRADO, p. 420).

O tratamento genérico da poluição, pelo Art. 54, encerra a antiga controvérsia, versada sobre os Arts. 270 e 271, a respeito da definição de água potável para fins de responsabilização penal. A partir de então, não mais se exige requisito da potabilidade, melhor entendida como a qualidade da água segura e palatável para consumo humano (ART, p. 15), já que a pureza bioquímica da água é um estado de difícil obtenção até mesmo em laboratório (KUWABARA, p. 3).

O Art. 270 do Código Penal prevê pena de reclusão de dez a quinze anos ao indivíduo que praticar a conduta de "envenenar água potável, de uso comum ou particular, ou substância alimentícia ou medicinal destina a consumo", incorrendo na mesma pena aquele que "entrega a consumo ou tem em depósito, para o fim de ser distribuída, a água ou a substância envenenada" ( $\$ 1$ ), admitindo-se a modalidade culposa no $\S 2$, a que se cominada pena de detenção de seis meses a dois anos.

A amplitude do termo utilizado pela Lei n.ㅇ 9.605/98 - poluição de qualquer natureza - abrange a primeira parte do Art. 270, uma vez que "veneno", apesar da obscuridade conceitual, pode ser perfeitamente considerado espécie de "poluição". Assim, é forçoso reconhecer a derrogação desta primeira parte, reforçada, aliás, pela qualificadora do $\S 2$, II do Art. 54 da Lei de crimes ambientais, incidente, como se viu, quando necessária a interrupção do abastecimento público de água (PRADO, 2006, p. 510). 
Já o Art. 271 concerne à corrupção ou poluição de água potável, "de uso comum ou particular, tornando-a imprópria para consumo ou nociva à saúde", conduta para a qual é prevista sanção penal de reclusão de dois a cinco anos, admitindo-se a modalidade culposa no parágrafo único, cuja pena passaria a ser de detenção, de dois meses a um ano.

A revogação tácita de ambos os dispositivos - primeira parte do Art. 270 e Art. 271 inteiramente - é questão praticamente vencida doutrina pátria (PRADO, 2006, p. 147-169). Há autores, entrementes, que, ao tratar do crime de poluição na Lei n.o 9.605/98, tão-só aludem à revogação do Art. 15 da Lei n.o 6.983/81 (BUGALHO, p. 16).

De outro lado, Carlos Ernani Constantino não esposa o entendimento de que houve revogação da primeira parte do Art. 270 do Código Penal, apoiando-se na diferença existente entre esse dispositivo e o Art. 54 da Lei de crimes ambientais.

Segundo este entendimento, "o art. 270 do CP pune a conduta do indivíduo que envenena (coloca veneno em) água potável (própria para ser bebida), ao passo que o Art. 54 da Lei Ambiental não faz tal distinção [...] Se alguém, pois, corromper água não potável, por meio de substância outra que não seja veneno, e ocasionar, com isso, poluição ambiental considerável, sua atuação será típica perante o Art. 54 da Lei n.⒐605/98 e não em face do Art. 270, §1ㅇdo CP” (CONSTANTINO, 2002, p. 186, grifo do autor).

Não procede esta argumentação, justamente porque a descrição típica do Art. 54 é mais abrangente, incluindo o envenenamento e a modalidade potável ${ }^{11}$ de água, além de tutelar, ao mesmo tempo, o ambiente e a saúde pública, como se verá em momento oportuno.

O mesmo raciocínio foi utilizado para propugnar pela completa vigência do Art. 271, que exigiria a potabilidade da água para a conformação típica (CONSTANTINO, p. 187), igualmente descabido.

A respeito do Art. 15 da Lei n. $06.938 / 98^{12}$, há de se pontuar que não procede o entendimento pela não revogação deste dispositivo pelo Art 54 da Lei de Crimes Ambientais,

11 Como bem se esclarece, "parece-nos mais acertado entender como potável não apenas as águas essencialmente puras, mas também aquelas passíveis de regular consumo pela população" (CARVALHO, É. M., op. cit., p. 62).

12 Rezava o Art. 15 da Lei n. 9.605/98: “O poluidor que expuser a perigo a incolumidade humana, animal ou vegetal, ou estiver tornando mais grave situação de perigo existente, fica sujeito à pena de reclusão de 1 (um) a 3 (três) anos e multa de 100 (cem) a 1.000 MVR. §1으 A pena é aumentada até o dobro se: I resultar: a) dano irreversível à fauna, à flora e ao meio ambiente; b) lesão corporal grave; II - a poluição é decorrente de atividade industrial ou de transporte; III - o crime é praticado durante a noite, em domingo 
uma vez que este trata a poluição de forma mais abrangente (BUGALHO, p. 16) ${ }^{13}$, além de comportar modalidade culposa, consagrada no $\S 1$ ‥

Passa-se, nas linhas que seguem, a analisar o Art. 54 da Lei n. 9.605/98, com especial enfoque à poluição hídrica, no que concerne ao bem jurídico protegido, a tipicidade objetiva e subjetiva, os sujeitos do delito, pena e ação penal, bem como a estrutura da forma qualificada prevista.

\section{0 art. 54 da lei $n .99 .605 / 98$}

Dez anos após a promulgação da Constituição Federal, o legislador infraconstitucional, por meio da Lei n.o 9.605/98 e com o fim de atender às novas expectativas de preservação ambiental, procura, bem ou mal, sistematizar em um só corpo normativo uma série de tipos penais existentes em leis esparsas (MILARÉ, p. 94).

Lamentavelmente, tal escopo não foi atingido pela referida lei, que se revela tecnicamente imperfeita, casuística, em total descompasso com princípios penais clássicos de garantia e as modernas exigências do Direito Penal (PRADO, p. 91).

O tratamento do crime de poluição pela referida lei reflete algumas destas imperfeições. Delimita o Art. 54 da Lei n. $9.605 / 98^{14}$ a prática da conduta de "causar poluição de qualquer natureza em níveis tais que resultem ou possam resultar em danos à saúde humana, ou que provoquem a mortandade de animais ou a destruição significativa da

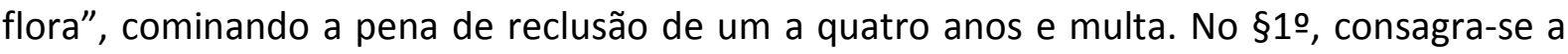
modalidade culposa e nos incisos do $§ 2^{\circ}$, sua forma qualificada.

ou em feriado; §2o Incorre no mesmo crime a autoridade competente que deixar de promover as medidas tendentes a impedir a prática das condutas acima descritas"

13 Neste ponto, insta notar que a redação do Art. 15 da Lei n.o 6.938/81, ao contrário dos dispositivos do Código penal, não indicava restrições quanto à qualidade da água; todavia, apresentava defeitos e lacunas que dificultavam extremamente sua aplicação (DARIVA, S. L., op. cit., p. 62).

14 Lei n. 9.605/98 “Art. 54. Causar poluição hídrica de qualquer natureza em níveis tais que resultem ou possam resultar em danos à saúde humana, ou que provoquem a mortandade de animais ou a destruição significativa da flora: Pena - reclusão, de 1 (um) a 4 (quatro) anos, e multa; §1ㅇ Se o crime é culposo: Pena detenção, de 6 (seis) a 1 (um) ano, e multa; §2으 Se o crime: I - tornar uma área, urbana ou rural, imprópria para a ocupação humana; II - causar poluição atmosférica que provoque a retirada, ainda que momentânea, dos habitantes das áreas afetadas, ou que cause danos diretos à saúde da população; III causar poluição hídrica que torne necessária a interrupção do abastecimento público de água de uma comunidade; IV - dificultar ou impedir o uso público das praias; $\mathrm{V}$ - ocorrer por lançamento de resíduos sólidos, líquidos ou gasosos, ou detritos, óleos ou substâncias oleosas, em desacordo com as exigências estabelecidas em leis ou regulamentos: Pena - reclusão, de 1 (um) a 5 (cinco) anos; §3o Incorre nas mesmas penas previstas no parágrafo anterior quem deixar de adotar, quando assim o exigir a autoridade competente, medidas de precaução em caso de risco de dano ambiental grave ou irreversível". 


\subsection{Bem jurídico protegido e sujeitos do delito}

Assenta-se, modernamente, que o desiderato maior do Direito Penal consiste na proteção de bens jurídicos vitais ao indivíduo e à comunidade (PRADO, 2003, p. 65). Assim, parte-se da noção de bem jurídico como "um ente (dado ou valor social) material ou imaterial haurido no contexto social, de titularidade individual ou metaindividual reputado como essencial para a coexistência e o desenvolvimento do homem em sociedade e, por isso, jurídico-penalmente protegido", necessariamente "em compasso com o quadro axiológico (Wertbild) vazado na Constituição e com o princípio do Estado Democrático e Social de Direito" (PRADO, p. 52-53).

Ainda que a legislação federal anterior à nova ordem constitucional revelasse certa preocupação com a preservação ambiental, somente a partir da Carta de 88 o ambiente conquista o status de bem jurídico-penal autônomo, passando a demandar uma tutela mais rigorosa e eficaz.

Indubitavelmente, a intervenção penal se faz necessária na proteção ambiental, contudo, deve restringir-se às formas mais graves de ofensa a este bem jurídico tão relevante, além de restar sempre norteada pelos princípios penais clássicos de garantia (LUISI, 2003, p. 100).

O ambiente constitui um bem jurídico-penal de titularidade supra-individual e caráter difuso, próprio do Estado Social de Direito, merecedor de tutela penal já que se faz essencial "para o desenvolvimento das potencialidades do ser humano enquanto pessoa, bem como sua real integração (social, política, cultural e econômica) em uma coletividade organizada" (PRADO, p. 107).

Cumpre salientar, neste ínterim, que não há uma relação hierárquica entre bens individuais e metaindividuais, mas sim uma relação de complementariedade (PRADO, p. 119). Vale dizer, na tutela de bens jurídicos supra-individuais, há sempre uma referência individual, que será mais ou menos acentuada conforme o caso. Isto é assim porque o homem não pode ser convertido em "meio" para realização dos fins do Estado (PRADO, p. 108), constatação diretamente decorrente do fundamento ético maior da dignidade humana. 
Neste sentido, tem-se que o Art. 54 da Lei n.o 9.605/98 tutela, ao mesmo tempo, o ambiente e a saúde pública $^{15}$, figurando, pois, um delito pluriofensivo (PRADO, 2006, p. 238). Como o dispositivo em foco trata a poluição ambiental de forma genérica, sendo apenas possível vislumbrar especificidade quanto ao patrimônio hídrico nas formas qualifica das, no crime de poluição de águas tutela-se, além da saúde pública, o ambiente, "com particular ênfase aos corpos hídricos (cursos d'água, rios, lagos, açudes, lagoas ou águas jurisdicionais brasileiras)"(DARIVA, p. 64).

Por outro lado, é comum na doutrina pátria aludir-se tão-só ao ambiente como o bem jurídico tutelado pelo Art. $54^{16}$. Não prospera tal entendimento, uma vez que o caput do referido artigo faz expressa alusão à proteção da saúde humana ${ }^{17}$, em relação à qual prevê, inclusive, a possibilidade de conformação típica com a existência de perigo concreto.

Trata-se de um crime comum, em que qualquer pessoa - e, conforme a concepção aqui perfilhada, tão-só pessoa física - pode figurar como sujeito ativo. Ante a natureza supraindividual do bem jurídico tutelado (BUGALHO, p. 17), apresenta-se como sujeito passivo do delito a coletividade (PRADO, 2006, p. 147).

A responsabilização penal da pessoa jurídica é um tema ainda muito controvertido na doutrina nacional. Passos de Freitas (p. 170), Milaré e Costa Júnior (p. 147), Sirvinskas (p. 185) entendem ser perfeitamente possível o ente moral figurar como sujeito ativo nos delitos ambientais. Resta equivocado tal entendimento, uma vez que a responsabilidade penal da pessoa coletiva encontra seu primeiro - e intransponível - obstáculo no princípio

15 “A saúde pública constitui bem jurídico supra-individual, de caráter coletivo, que tem em conta a saúde individual, mas que com ela não se confunde, ainda que objetive salvaguardá-la" (PRADO, L. R., Direito Penal do Ambiente, p. 417). Em um sentido mais restrito, porém reconhecendo que não há apenas tutela do bem jurídico ambiente, tem-se o posicionamento de Waldir Sznick, segundo o qual seriam os bens jurídicos protegidos: saúde, a fauna e a flora (SZNICK, Valdir. Direito Penal Ambiental. São Paulo: Ícone, 2001, p. 381). Não parece tecnicamente correta esta assertiva, uma vez que a fauna e a flora constituem os elementos naturais pertencentes ao ambiente, que se intenta preservar por meio da incriminação (CARVALHO, Érika Mendes de. Tutela penal do patrimônio florestal brasileiro. São Paulo: RT, 1999, p. 140).

16 Neste sentido: CONSTANTINO, C. E., op. cit., p. 182, que utiliza a expressão "objeto jurídico do delito", ao invés de bem jurídico protegido; FREITAS, V. P. de; FREITAS, G. P. de, Crimes contra a natureza, p. 170, que também optam pela expressão "objeto jurídico"; De seu turno, Édis Milaré e Paulo José da Costa Júnior fazem referência à "objetividade jurídica" (MILARÉ, É; COSTA JÚNIOR, P. J. da, op. cit., p. 146); SIRVINSKAS, Luís Paulo. Tutela penal do meio ambiente. Breves considerações atinentes à Lei n.o 9.605/98. 2. ed. São Paulo: Saraiva. 2002, p. 184.

17 Neste sentido, nota-se que a referência que faz o caput do Art. 54 à saúde humana desvela a pretensão de "tutelar a saúde pública, não importando se o comprometimento desta é resultado de poluição atmosférica, do solo, da água, sonora, etc [...]" (BULGALHO, Nelson Roberto. Reflexões sobre a objetividade jurídica do injusto penal da poluição. Revista de Direito Ambiental, São Paulo, a.7, n. 26, p. 168-181, abr./jun. 2002. p. 176). 
da imputação penal subjetiva, um dos pilares de um Direito Penal verdadeiramente democrático (PRADO, 2001).

\subsection{Tipicidade objetiva e subjetiva}

Convém enfatizar, em um primeiro momento, que "o Direito Penal é, por excelência, um Direito tipológico", sendo que o tipo legal descreve abstratamente um fato real - ação ou omissão, dolosa ou culposa - que a lei proíbe (PRADO, p. 339). O tipo, enquanto tipo de injusto, compreende "todos os elementos que fundamentam o injusto específico de uma conduta delitiva" (CEREZO, p. 476).

Como se sabe, o tipo de injusto de ação doloso decompõe-se, didaticamente, em tipo objetivo e subjetivo que, em realidade, não se opõem, mas conformam a "unidade subjetiva-objetiva da conduta típica"(PRADO, p. 347).

Relativamente ao delito de poluição hídrica, intenta-se, nas linhas que seguem, analisar o tipo objetivo e subjetivo do delito consubstanciado no caput do Art. 54, bem como as formas qualificadas concernentes à tutela do patrimônio hídrico.

O núcleo do tipo consiste no verbo "causar", que significa "dar causa", originar, produzir. Trata-se de um delito comissivo, havendo previsão expressa da modalidade comissiva por omissão no §3ำ do mesmo artigo.

A primeira observação a ser feita com relação ao caput deste artigo concerne à imprecisão de seu conteúdo de injusto, que abusa de "cláusulas normativas, de cunho valorativo, que estão muito aquém das exigências do princípio da legalidade, em sua vertente taxatividade-determinação da lei penal" (PRADO, p. 418).

O princípio da determinação, constitucionalmente consagrado, representa uma das lídimas exigências do Estado de Direito, porquanto assegura a "específica eticidade do direito", por meio da certeza jurídica, atendendo à própria cognoscibilidade da norma e, sobretudo, impondo-se como limite ao poder punitivo estatal (PALAZZO, 1989, p. 50).

O referido postulado preconiza que as normas penais, sobretudo as incriminadoras, devem ser claras, revestidas de maior certeza e precisão possíveis, para que o seu destinatário tenha condições de compreender o seu conteúdo e obedecer a seu mandamento ou proibição (LUISI, p. 24). 
A ofensa à determinação é deflagrada das expressões "em níveis tais" e "destruição significativa", que integram um âmbito de imprecisão conceitual e insegurança jurídica nocivas à proteção da liberdade individual ${ }^{18}$.

Tais expressões, entendidas como corretivos típicos, teriam o condão de excluir "do âmbito do injusto típico as condutas escassamente lesivas ou de pouca relevância para o bem jurídico tutelado" (PRADO, p. 419).

Faz-se necessário esclarecer, por oportuno, que tais expressões constituem elementos normativos de valoração extrajurídica ${ }^{19}$, componentes do tipo objetivo do injusto, como também o são as expressões "poluição" e "de qualquer natureza" (DARIVA, p. 66). De seu turno, as palavras "animais" e "flora" figuram elementos descritivos do tipo objetivo.

É de se notar, inevitavelmente, que o legislador abusou dos elementos normativos, mormente por se tratarem de elementos extrajurídicos, que demandam juízos de valor "fundados na experiência, na sociedade ou na cultura" (PRADO, p. 349). Em contrapartida, faz pouco uso dos elementos descritivos, mais aptos a garantir a segurança jurídica tão rogada pelo princípio da determinação.

18 Criticando a excessiva indeterminação dessas expressões, também: MALUCELLI, M., op. cit., p. 154; MILARÉ, É; COSTA JÚNIOR, P. J. da, op. cit., p. 147. Em sentido contrário e, pois, louvando a escolha legislativa na utilização destes elementos normativos: ADEDE Y CASTRO, J. M., op. cit., p. 222, para quem "a interpretação do direito ambiental e notadamente do 'caput' do artigo 54 deve ser feita em favor da sociedade, pois o texto não é lacunoso, como alguns dizem, bastando que queiramos vê-lo como um instrumento sincero e efetivo de defesa do meio ambiente". Paulo Affonso Leme Machado assevera também que não é pertinente a censura feita ao emprego das expressões "de qualquer natureza" e "em níveis tais", por estarem "fortemente ligadas à possibilidade de causar perigo ou dano aos bens protegidos", sem, contudo, gerar arbítrio judicial ou insegurança ao acusado (LEME MACHADO, P. A., op. cit., p. 678). Entrementes, não Ihes assiste razão, pois a lesão ao princípio da legalidade, em sua vertente taxatividade ou determinação, é flagrante e, como se sabe, a legitimidade de qualquer intervenção penal é questionável na medida em que atente a princípios penais clássicos de garantia; e isto não significa, de forma alguma, a defesa de degradadores ambientais em detrimento da proteção ecológica.

De um modo bem sucinto, é pertinente esclarecer que dentre os elementos do tipo objetivo, que fundamentam o injusto próprio de determinada conduta delitiva, faz-se a distinção entre elementos descritivos e normativos, podendo estes ser jurídicos ou extrajurídicos. Os primeiros consistem naqueles identificáveis facilmente pela percepção sensorial, enquanto os últimos demandam um juízo de valor, referente a uma realidade constante na ordem jurídica ou não (PRADO, L. R., Curso de Direito Penal Brasileiro, v. 1, p. 348). 
Não obstante o tratamento genérico de poluição ambiental conferido pelo caput do Art. 54 da Lei n. 9.605/98, há expressa referência à poluição hídrica nas formas qualificadas: $\S 2$, incisos III, IV e V20.

No inciso III, a expressão "poluição hídrica" é o elemento normativo de valoração extrajurídica ${ }^{21}$ do tipo, enquanto que "água" e "comunidade" podem ser classificados como elementos descritivos do tipo. Por sua vez, nos incisos IV e $V$ há, respectivamente, os elementos descritivos "praias" e "resíduos sólidos", "líquidos", "óleos ou substâncias oleosas".

Outra questão de suma relevância concerne à classificação do crime de poluição em delito de resultado ou de perigo. Com relação ao caput do Art. 54, afirma-se que se trata de um delito de resultado ou de perigo concreto (PRADO, p. 420) no tocante à saúde humana ("resultem ou possam resultar danos à saúde humana") e, por outro lado, configura-se tãosó delito de resultado quanto aos danos exclusivamente ambientais, uma vez que exige a concreta "mortandade de animais" ou "destruição significativa da flora".

A tutela penal dos interesses supraindividuais caracteriza-se pela presença dos chamados delitos de perigo, sobretudo os de perigo abstrato, ante os obstáculos existentes para confirmação de um dano evidente (JORGE SILVEIRA, 2003, p. 89) ou, ainda, a difícil verificação da relação causal entre vontade e resultado (PRADO, p. 134).

Os delitos de perigo são aqueles em que basta a existência de uma situação de perigo para a conformação típica (PRADO, p. 241); subdividem-se em delitos de perigo concreto e abstrato, cuja diferença reside na constatação do perigo existente: nos primeiros, o perigo constitui um elemento normativo do tipo, ou seja, a realização do tipo objetivo está condicionada à comprovação de real existência de perigo ao bem jurídico protegido (PRADO, p. 136) $)^{22}$. Nos delitos de perigo abstrato, ao contrário, não há necessidade de comprovação

20 §2.o Se o crime: (...) III - causar poluição hídrica que torne necessária a interrupção do abastecimento público de água de uma comunidade; IV - dificultar ou impedir o uso público das praias; $\mathrm{V}$ - ocorrer por lançamento de resíduos sólidos, líquidos ou gasosos, ou detritos, óleos ou substâncias oleosas, em desacordo com as exigências estabelecidas em leis ou regulamentos: Pena - reclusão, de 1 (um) a 5 (cinco) anos.

21 Como se observou anteriormente, houve diversas tentativas de conceituar poluição hídrica por meio de sucessivos diplomas legais, dentre os quais nenhum atingiu satisfatoriamente uma definição condizente a moderna diretiva de preservação ambiental.

22 Os delitos de perigo concreto são, do ponto de vista dogmático, delitos de resultado de perigo (CEREZO MIR, José. Los delitos de peligro abstracto en el ámbito del derecho penal del riesgo. Obras completas. Otros estudios, tomo II. Lima: ARA, 2006, p. 469). 
de perigo no caso concreto, justamente por constituir a ratio legis, isto é, o motivo pelo qual o legislador proíbe determinada conduta (PRADO, p. 241).

No caso em tela, em se tratando de danos à saúde humana, resta evidente que o perigo figura como elemento normativo do tipo, havendo a necessidade de sua comprovação no caso concreto. Não obstante, há autores que afirmam tratar-se, neste particular, de um delito de perigo abstrato (BUGALHO, p. 20) 23 .

O tipo subjetivo consubstancia-se no dolo, vontade livre e consciente de realização dos elementos do tipo objetivo (PRADO, p. 421), sendo a modalidade culposa insculpida no $\S 1$ o do artigo sob comento.

Conforme se observou anteriormente, o §2ㅇ do Art. 54 consagra as formas qualificadas do crime de poluição. Convém advertir, primeiramente, que as circunstâncias qualificadoras modificam as margens penais do tipo básico, vale dizer, dão lugar a tipos derivados, aos quais se cominam novas penas (PRADO, 1999, p. 128-142).

Urge observar que nas qualificadoras compreendidas pelos incisos III e IV, o agravamento da pena se dá em razão de um maior desvalor do resultado da conduta típica. Assim, o delito de poluição hídrica se perfaz com a alteração das propriedades físicas, químicas ou biológicas da água, da qual "decorram ou possam decorrer - probabilidade dano à saúde do homem, ou morte em grande número de animais ou devastação grave da flora" (PRADO, p. 423). A pena é agravada, conforme se depreende da alteração das margens penais, caso sobrevenha a ingente necessidade de se interromper o abastecimento público de água de uma comunidade (inciso III) ou, ainda, torne-se custoso ou completamente impedido o uso público das praias (inciso IV). Obviamente, o resultado que qualifica o delito deve ocorrer ao menos culposamente, em consonância com o princípio da responsabilidade penal subjetiva e o disposto no Art. 19 do Código Penal.

Sem adentrar, por ora, na questão da alteração das margens penais, insta destacar a qualificadora relacionada no inciso $\mathrm{V}$ que, a nosso ver, não se aplica unicamente à poluição hídrica, mas também à atmosférica e do solo.

23 Note-se a contrariedade destes últimos autores que, em um primeiro momento, classificam a primeira parte do delito como de perigo abstrato e, em seguida, postulam pela imprescindibilidade de perícia que "ateste a efetiva existência de perigo à saúde ou de dano à saúde humana [...]". 
O legislador lançou mão, neste caso, de uma norma penal em branco ${ }^{24}$, que constitui, ao mesmo tempo, elemento normativo do tipo relativo a uma possível causa de justificação (PRADO, p. 424), consubstanciada na expressão "em desacordo com as exigências estabelecidas em leis ou regulamentos". Provavelmente o intento do legislador consistiu em punir mais severamente aquele que desobedece às normas administrativas, uma vez que "resíduos sólidos, líquidos ou gasosos, ou detritos, óleos ou substâncias oleosas" já restam incorporados à noção de poluição.

Por fim, conforme o §3을 do Art. 54, incorrerá nas mesmas penas do §2a aquele que "deixar de adotar, quando assim o exigir a autoridade competente, medidas de precaução em caso de risco de dano ambiental grave ou irreversível". Trata-se de um crime omissivo impróprio (PRADO, p. 420), em que se reconhece o princípio da precaução (SIRVINSKAS, p. 189).

A conduta omissiva consiste em não tomar as providências necessárias e aptas a evitar o dano intenso, de difícil reparação, ou irreversível, isto é, que não se pode fazer voltar ao estado anterior ${ }^{25}$.

A exigência da autoridade competente para tomada de certas medidas de precaução denota norma penal em branco (PRADO, p. 424); são exemplos destas providências de precaução a instalação ou troca de filtros nas indústrias e a adoção de instrumentos de "depuração de dejetos sólidos, líquidos ou gasosos" (PRADO, p. 424), etc.

\subsection{Pena e ação penal}

A pena cominada ao crime de poluição doloso é de reclusão de um a quatro anos e multa. À modalidade culposa prevê-se pena de detenção, de seis meses a um ano e multa $(\S 10$ ). No tocante às formas qualificadas e à omissão imprópria, consagradas, respectivamente, nos parágrafos 2 e 3 , as margens penais passam a ser de um a cinco

24 Denomina-se norma penal em branco aquela em que "a descrição da conduta punível se mostra incompleta ou lacunosa, necessitando de outro dispositivo legal para sua integração ou complementação" (PRADO, L. R., Curso de Direito Penal Brasileiro, v. 1, p. 173). É inequívoca a importância deste instrumento na regulação penal do ambiente, sobretudo em razão da estreita relação que guarda com o Direito Administrativo e da própria mutabilidade e complexidade que enseja tão relevante matéria (CEREZO MIR, José. Las leyes penales en blanco en la protección penal del medio ambiente. Obras completas. Otros estudios, tomo II. Lima: ARA, 2006, p. 379).

25 qualidade do risco de dano como "grave" ou "irreversível" denotam também "corretivos típicos", de modo a afastar danos de pouca relevância (PRADO, L. R., Direito Penal do Ambiente, p. 424). 
anos, suprimida a aplicação de multa. A ação penal é pública incondicionada em qualquer caso.

Neste particular, insta questionar a pertinência da previsão de formas qualificadas, uma vez que não houve, de fato, modificação significativa das margens penais - acréscimo de um ano à pena máxima - e, além disso, deixou o legislador, propositalmente ou não, de prever a pena de multa juntamente com a pena de reclusão.

A má técnica legislativa, neste caso, permite a suspensão condicional do processo (Art. 89 da Lei 9.099/95) ao crime de poluição hídrica qualificado pelo resultado mais grave, por exemplo, a necessidade de se interromper o abastecimento público de água de uma comunidade. Arrisca-se afirmar, por fim, que a tentativa de punição mais severa dos casos especificados nos incisos do §2으 e do §3ํe é meramente simbólica.

Agregue-se, por oportuno, a contradição em que incidiu o legislador de 98 ao estabelecer o critério de cálculo da pena de multa. O Art. 18 da Lei n.o 9.605/98 determina que a pena de multa será calculada segundo os critérios do Código Penal, acrescentando que, no caso de ineficácia, ainda que aplicado o máximo valor possível, poderá ser aumentada em até três vezes, conforme o valor da vantagem econômica auferida.

Como se sabe, o sistema de cominação de multa (PRADO, 1993) instituído pelo Código Penal brasileiro (Art. 49) é o chamado sistema de "dias-multa". Trata-se de uma construção originariamente brasileira, consistente em "determinar a pena de multa não por uma soma em dinheiro (quantidade fixa), como no sistema tradicional, mas por um número de unidades artificiais, segundo a gravidade da infração" (PRADO, p. 613).

Primeiramente, o juiz determina a quantidade de dias-multa, que exprime o conteúdo de injusto e de culpabilidade da ação; em um segundo momento, o magistrado fixa o valor pertinente a cada dia-multa, conforme a capacidade econômica do condenado. 0 valor da sanção é obtido mediante a multiplicação da quantidade de dias-multa estabelecida pelo valor fixado de cada uma destas unidades artificiais (PRADO, p. 613-614). No §1으 do Art. 60 do Código Penal, há a previsão de aumento deste valor total, quando se revelar ineficaz, até o triplo, em virtude da situação econômica do réu.

É de se notar que, além da diversidade dos fatores estabelecidos pelo Art. 18 da Lei dos crimes ambientais e pelo Código Penal para o aumento da pena de multa quando o valor máximo determinável revelar-se ineficaz, o Art. 19 da mencionada Lei dispõe que o laudo 
pericial de constatação de dano ambiental fixará, sempre que possível, um montante referente ao prejuízo causado "para efeitos de prestação de fiança e cálculo de multa".

Para além da incerteza acerca de qual critério deva ser considerado na fixação e gradação da multa, denota-se um problema ainda mais inaceitável: o "valor da vantagem econômica auferida", quase sempre corresponde ao "montante do prejuízo causado", integrante do desvalor do resultado do injusto que, por seu turno, já é objeto de apreciação pelo magistrado na primeira fase de cominação da pena de multa, quando considera a gravidade do injusto penal. Trata-se, pois, de uma flagrante violação ao princípio ne bis in idem (PRADO, p. 192).

\section{Conclusão}

A poluição do ambiente hídrico caracteriza-se como uma das formas de degradação ambiental mais alarmantes da atualidade. Os desenfreados processos de industrialização e avanço tecnológico, o conseqüente aparecimento de grandes aglomerados urbanos, o deslocamento da população rural para esses centros industriais, constituem, em síntese, os principais fatores de incremento do processo de poluição, devido ao lançamento de resíduos industriais, esgotos sanitários, entre outros elementos nocivos, no ambiente, em que há maior afetação do ar atmosférico e dos recursos hídricos (KUWABARA, p. 1).

A legislação penal concernente à tutela do patrimônio hídrico, antes do advento da Lei Fundamental de 1988, revelava-se particularmente circunstancial, carecedora de uma consideração global do ambiente enquanto bem jurídico autônomo e, por isso, de escassa aplicabilidade (CARVALHO, p. 65).

Atualmente, o tratamento jurídico-penal da poluição hídrica encerra-se no Art. 54 da Lei n.o 9.605/98 que, dispondo amplamente sobre a poluição ambiental, revogou a primeira parte do Art. 270 e todo o Art 271 do Código Penal e o Art. 15 da Lei n. 6.938/81, além de prever a modalidade culposa e omissiva imprópria.

É comum afirmar-se que o Art. 54 da Lei n.o 9.605/98 representou um grande avanço no tratamento penal da poluição em geral (BUGALHO, p. 16). De fato, quando em cotejo com o tratamento penal anterior, o citado dispositivo revela, aparentemente, maior preocupação legislativa com a preservação ambiental, consolidando-o como bem jurídico dotado de substancialidade própria. 
Entretanto, a excessiva amplitude e indeterminação típica do Art. 54, além de violar o princípio da legalidade, em seu postulado da determinação, conduzem a um sério questionamento acerca da própria efetividade da norma.

Cumpre advertir, neste passo, que a própria preferência do legislador em tutelar o ambiente por meio de lei extravagante não foi a mais adequada, mormente em razão da relevância do ambiente enquanto bem jurídico autônomo, já que "as leis especiais somente devem ser utilizadas para as infrações de apoucada gravidade ou em casos excepcionais e restritos" (PRADO, p. 89).

Desta feita, preferível seria que o legislador tivesse seguido a mesma orientação do Anteprojeto da Parte Especial do Código Penal ${ }^{26}$, anteriormente referido, divisando as diversas formas de poluição ambiental em tipos penais autônomos (DARIVA, p. 63).

A tentativa do legislador de concentrar, em um único tipo penal, todas as formas possíveis de conduta poluidora conduz a uma temerária indeterminação típica, flagrantemente contrária às exigências do princípio da legalidade, em seu postulado da determinação que, enquanto verdadeiro postulado de "legitimação democrática, deve informar e presidir a atividade de produção normativa penal, por força da particular relevância dos bens em jogo" (PRADO, p. 67).

Os bens jurídicos tutelados pelo Art. 54 da Lei n. 9.605/98 são o ambiente, em particular os corpos hídricos no tocante à poluição hídrica, e a saúde pública, cuidando-se, pois, de um delito pluriofensivo.

Com relação aos prejuízos ambientais provenientes da conduta poluidora mortandade de animais e destruição significativa da flora - , o delito é de resultado; de outro lado, no concernente aos danos à saúde humana, cuida-se de perigo concreto.

A previsão da modalidade culposa no $\$ 1$ ㅇ do Art. 54 da referida lei certamente supriu uma lacuna da legislação anterior, em relação a qual recaíam diversas críticas, mormente em vista da dificuldade de se comprovar, na prática, o dolo "nas condutas lesivas ao ambiente" (CARVALHO, p. 67).

As formas qualificadas concernentes à poluição hídrica estão relacionadas no $2^{\circ}=$ do mesmo artigo, incisos III, IV e V. A pena cominada às formas qualificadas e à modalidade

26 No tocante à poluição hídrica, o Anteprojeto reservava dois dispositivos (Art. 401 e 402) que dispunham, respectivamente, sobre a poluição de águas interiores de superfícies ou subterrâneas e sobre a poluição de estuário, mangues ou águas litorâneas. 
omissiva do §3ㅇ é de um a cinco anos, sem a multa prevista cumulativamente no caput, razão pela qual é oportuno asseverar que o tratamento mais severo pretendido pelo legislador não se mostra eficaz.

O ambiente hídrico certamente constitui bem jurídico carecedor de tutela penal; a poluição, neste sentido, é uma das formas de agressão ambiental mais incisivas, a qual não se pode deixar de criminalizar. A intervenção penal, não obstante, deve se dar de maneira racional, em compasso com os princípios penais fundamentais de garantia individual, sob pena de revelar-se inconstitucional e, portanto, ilegítima.

O presente tratamento jurídico-penal da poluição hídrica, concentrado no Art. 54 da Lei n.o 9.605/98, revela-se estéril tanto em razão da má técnica legislativa empregada na elaboração do tipo penal, quanto pela ausência de mecanismos eficazes de fiscalização, controle, prevenção e reparação.

Apenas por meio de uma legislação penal compatível com os princípios clássicos de grantia, que não se afaste da concepção do homem como o centro de todo o Direito, será possível preservar efetivamente o ambiente e promover o desenvolvimento econômico aliado a uma utilização racional dos recursos naturais.

\section{Referências}

ADEDE Y CASTRO, João Marcos. Crimes ambientais: comentários à Lei n. 9.605/98. Porto Alegre: Sergio Antonio Fabris, 2004.

ART, Henry W. (editor geral). Dicionário de Ecologia e Ciências Ambientais. Trad. Mary Amazonas Leite de Barros. 2. ed. São Paulo: UNESP, Companhia Melhoramentos, 2001.

BRANCO, Samuel Murgel. Poluição: a morte de nossos rios. Rio de Janeiro: Cetesb, 1972.

BUGALHO, Nelson Roberto. Crime de Poluição, do Art. 54 da Lei 9.605/98. Revista de Direito Ambiental, São Paulo, v. 3, n. 11, p. 15-24, jul./set. 1998.

Reflexões sobre a objetividade jurídica do injusto penal da poluição. Revista de Direito Ambiental, São Paulo, v.7, n. 26, p. 168-181, abr./jun. 2002.

CARVALHO, Benjamin de Araújo. Ecologia e Poluição. Rio de Janeiro: Freitas Bastos, 1975. 
CARVALHO, Érika Mendes de. Alguns aspectos da tutela penal do ambiente hídricoatmosférico. Revista de Ciências Jurídicas, Maringá: Imprensa Universitária, v. 1, p. 53-69, 1997.

. Tutela penal do patrimônio florestal brasileiro. São Paulo: RT, 1999.

CEREZO MIR, José. Obras completas. Derecho Penal. Parte general, tomo I. Lima: ARA, 2006.

. Los delitos de peligro abstracto en el ámbito del derecho penal del riesgo. Obras completas. Otros estudios, tomo II. Lima: ARA, 2006.

. Las leyes penales en blanco en la protección penal del medio ambiente. Obras completas. Otros estudios, tomo II. Lima: ARA, 2006.

CONSTANTINO, Carlos Ernani. Delitos ecológicos. A lei ambiental comentada artigo por artigo. 2 ed. São Paulo: Atlas, 2002.

DARIVA, Silvia Luiza. Tutela Penal dos Recursos Hídricos. 2002. 110 p. Dissertação (Mestrado em Direito - sub-área de Direito Penal) - Universidade Estadual de Maringá, Maringá, 2002.

DERISIO, José Carlos. Introdução ao controle de poluição ambiental. 2. ed. São Paulo: Sigmus, 2000.

DORST, Jean. Antes que a natureza morra: por uma ecologia política. Trad. Rita Buongermino. São Paulo: Edgard Blücher, 1973.

DOTTI, René Ariel. Meio ambiente e proteção penal. Revista dos Tribunais,São Paulo, v. 655, p. 245-257, maio.1990.

FELLENBERG, Günther. Introdução aos problemas da poluição ambiental. Trad. Juergen Heinrich Maar. São Paulo: USP, 1980.

FERREIRA, Aurélio Buarque de Holanda. Novo dicionário Aurélio da língua portuguesa. 3. ed. Curitiba: Positivo, 2004.

FREITAS, Gilberto Passos de. Do crime de poluição. Direito Ambiental em evolução, n. 1. 2. ed. Curitiba, Juruá, 2005.

FREITAS, Vladimir Passos de. Águas - considerações gerais. Águas. Aspectos jurídicos e ambientais. 2 ed. p. 17-28.Curitiba, Juruá, 2006. 
FREITAS, Vladimir Passos de; FREITAS, Gilberto Passos de. Crimes contra a natureza. De acordo com a Lei 9.605/98. 7. ed. São Paulo: RT, 2001.

JORGE SILVEIRA, Renato de Mello. Direito Penal Supra-individual. Interesses difusos. São Paulo: RT, 2003.

KÖELER, Vera Beatriz; SAITO, Silvia Midori. Água é vida. In: GUERRA VILLALOBOS, Jorge Ulises (Org.). Ambiente, Geografia e Natureza. Maringá: Programa de Pós-graduação em Geografia - UEM, 2000.

KUWABARA, Deodoro Yasukazu. Poluição das Águas. 1982. 135 p. Monografia (Especialização em Química) - Universidade Estadual de Londrina, Londrina, 1982.

LEME MACHADO, Paulo Affonso. Direito Ambiental Brasileiro. 9. ed. São Paulo: Malheiros, 2001.

LUISI, Luiz. Os princípios constitucionais penais. 2. ed. Porto Alegre: Sergio Antonio Fabris, 2003.

MALUCELLI, Marcelo. Tutela Penal das Águas. In: FREITAS, Vladimir Passos de (Org.). Águas. Aspectos jurídicos e ambientais. 2. ed. Curitiba: Juruá, 2006. p. 147-169.

MELLANBY, Kenneth. Biologia da poluição. Trad. Lúcia Baungartner Lamberte. 2. ed. Inglesa.São Paulo: EPU (USP), 1982.

MILARÉ, Édis. Direito do ambiente. 3. ed. São Paulo: RT, 2004.

A nova tutela penal do ambiente. Revista de Direito Ambiental, São Paulo, v. 4, n. 16, p. 90-134, out./dez. 1999.

MILARÉ, Édis; COSTA JÚNIOR, Paulo José da. Direito Penal Ambiental. Comentários à Lei 9.605/98. Campinas: Millennium, 2002.

ODUM, Eugene P. Fundamentos de Ecologia. 7. ed. Lisboa: Fundação Calouste Gulbenkian, 2004.

PALAZZO, Francesco C. Valores Constitucionais e Direito Penal. Um estudo comparado. Trad. Gérson Pereira dos Santos. Porto Alegre: Sergio Antonio Fabris, 1989.

PIRANGELLI, José Henrique. Agressões à natureza e proteção dos interesses difusos. Revista dos Tribunais, São Paulo, v. 78, n. 649, nov. 1989. 
POMPEU, Cid Tomanik. Direito de Águas no Brasil. São Paulo: RT, 2006.

PRADO, Luiz Regis. Curso de Direito Penal Brasileiro, v.1. Parte Geral. 6. ed. São Paulo: RT, 2006.

. Curso de Direito Penal Brasileiro. 4. ed. São Paulo: RT, 2006. v. 3.

Direito Penal do Ambiente. Meio Ambiente. Patrimônio Cultural. Ordenação do Território. Biossegurança. São Paulo: RT, 2005.

. Bem jurídico-penal e Constituição. 3 ed. São Paulo: RT, 2003.

- (Coord.). Responsabilidade penal da pessoa jurídica: em defesa do princípio da imputação penal subjetiva. São Paulo: RT, 2001.

. O injusto penal e a culpabilidade como magnitudes graduáveis. Revista Brasileira de Ciências Criminais, São Paulo, v. 7, n. 27, p. 128-142, jul./set. 1999.

. Multa penal: doutrina e jurisprudência. 2. ed. São Paulo: RT, 1993.

RUFINO, Gilberto D'ávila. Aspectos jurídicos da poluição. A questão da poluição das águas. Revista de Direito Público, São Paulo, v. 95, p. 241-248, jul./set. 1990.

SALES, Sheila J. Selim de. Parte especial do Código e parte especial do Direito Penal: o problema da legislação complementar. Descodificação e recodificação. Critérios para a recodificação: novas tendências. Revista da $A B P C P$, São Paulo, v. 1, n. 1, p. 134-170, jul./dez. 2004.

SIRVINSKAS, Luís Paulo. Tutela penal do meio ambiente. Breves considerações atinentes à Lei n.o 9.605/98. 2. ed. São Paulo: Saraiva, 2002.

SZNICK, Valdir. Direito Penal Ambiental. São Paulo: Ícone, 2001.

WELZEL, Hans. Derecho Penal Alemán. Parte general. 11. ed. Trad. Juan Bustos Ramírez e Sergio Yánez Pérez. Santiago: Jurídica de Chile, 1970. 